\title{
The archaeology of persistent places: the Palaeolithic case of La Cotte de St Brelade, Jersey
}

Andrew Shaw ${ }^{1}$, Martin Bates ${ }^{2}$, Chantal Conneller ${ }^{3}$, Clive Gamble ${ }^{1}$,
Marie-Anne Julien ${ }^{1}$, John McNabb ${ }^{1}$, Matt Pope ${ }^{4} \&$ Beccy Scott

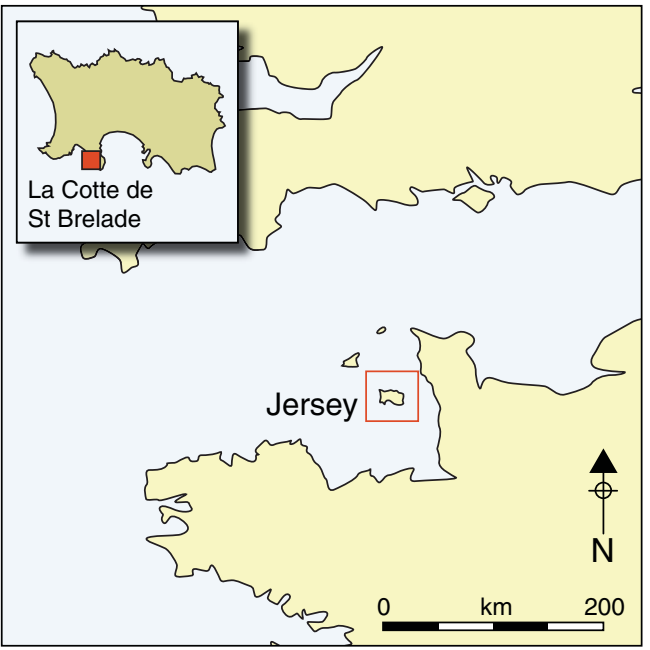

Excavations at the Middle Pleistocene site of La Cotte de St Brelade, on the island of Jersey in the English Channel, have revealed a long sequence of occupation. The continued use of the site by Neanderthals throughout an extended period of changing climate and environment reveals how, despite changes in the types of behaviour recorded at the site, La Cotte emerged as a persistent place in the memory and landscape of its early hominin inhabitants. The site's status as a persistent place for these people suggests a level of social and cognitive development permitting reference to and knowledge of places distant in time and space as long ago as at least MIS 7.

Keywords: Jersey, Middle Pleistocene, Neanderthals, persistent place, landscapes

\section{Introduction}

Recent interdisciplinary research has established the Middle Pleistocene as key to human behavioural evolution (Figure 1). Advances in Quaternary stratigraphy, science-based dating, molecular studies, palaeoecology and large-scale archaeological projects have transformed

1 Centre for the Archaeology of Human Origins (CAHO), Department of Archaeology, University of Southampton, Avenue Campus, Highfield, Southampton SO17 1BF, UK (Email: a.d.shaw@soton.ac.uk; clive.gamble@soton.ac.uk; m.julien@soton.ac.uk; j.mcnabb@soton.ac.uk)

2 Department of Archaeology, University of Wales Trinity Saint David, Lampeter SA48 7ED, UK (Email: m.bates@tsd.ac.uk)

3 Department of Archaeology, University of Manchester, Oxford Road, Manchester M13 9PL, UK (Email: chantal.conneller@manchester.ac.uk)

4 Institute of Archaeology, University College London, 31-34 Gordon Square, London WC1H OPY, UK (Email: m.pope@ucl.ac.uk)

5 Department of Britain, Europe and Prehistory, The British Museum, Franks' House, 38-55 Orsman Road, London N1 5QJ, UK (Email: rscott@britishmuseum.org)

(C) Antiquity Publications Ltd, 2016. This is an Open Access article, distributed under the terms of the Creative Commons Attribution licence (http://creativecommons.org/licenses/by/4.0/), which permits unrestricted re-use, distribution, and reproduction in any medium, provided the original work is properly cited.

ANTIQUITY 90354 (2016): 1437-1453

doi:10.15184/aqy.2016.212 

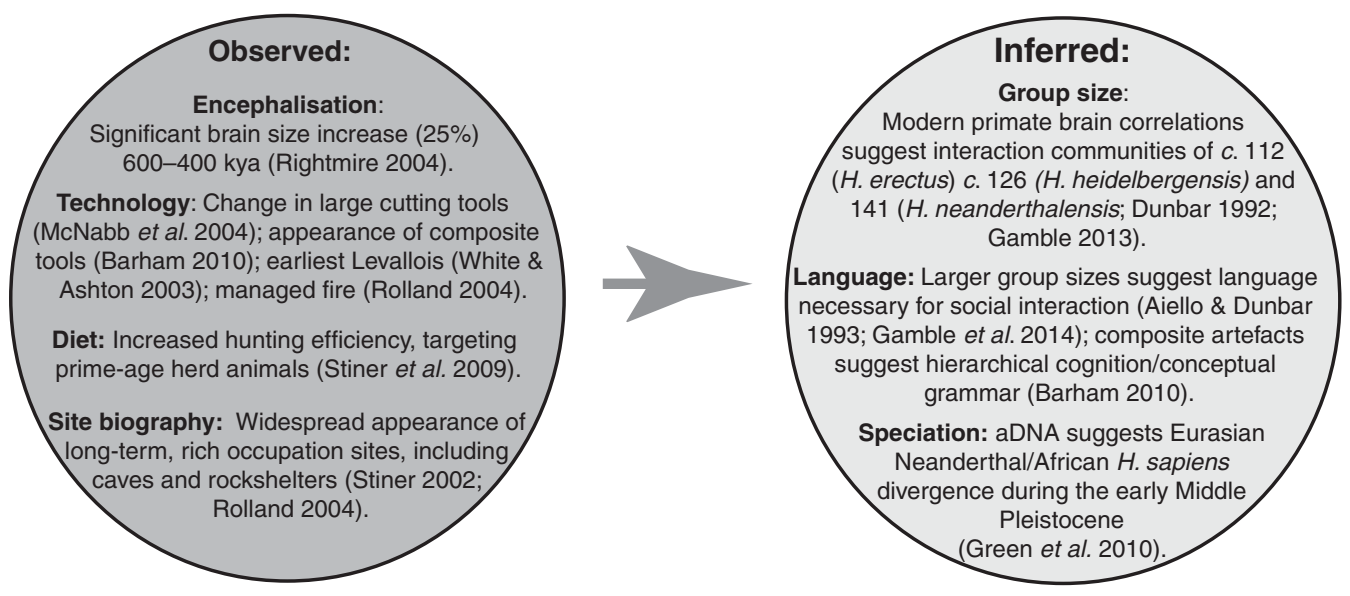

Figure 1. The significance of the Middle Pleistocene in human evolution. During cycles 5-2 of the Middle Pleistocene (MIS 15-7; 600 000-200000 years ago) the above global features of hominin evolution have been observed or inferred.

our understanding of the period 780 000-130 000 years ago (e.g. Ashton et al. 2011); the Middle Pleistocene is no longer merely a "muddle in the middle" (Butzer \& Isaac 1975: 875). Instead, a complex interplay between environmental process and adaptive human response has become apparent, calling into question the historical focus on an Upper Pleistocene 'human revolution', albeit one that has been thought (Mellars \& Stringer 1989; Klein 2008) and rethought (McBrearty \& Brooks 2000; Mellars et al. 2007; Shea 2011) many times.

In this article we present a first examination of the appearance of 'persistent places' (cf. Schlanger 1992) during the Middle Pleistocene: places hominins used repeatedly beyond ethnographic (generational) timescales, forming a focus of activity over geologically measurable periods, i.e. between glacial/interglacial cycles. We consider persistent places in the landscape as structuring features that must be investigated when considering changing hominin behaviour from a co-evolutionary perspective. The appearance of persistent places demonstrates that hominin niche construction is both a culturally constituted and ecologically informed activity: persistent places act as an index for hominin familiarity with, and enculturation of, landscapes. We illustrate this concept with a new analysis of Middle Pleistocene deposits from La Cotte de St Brelade, Jersey (Callow \& Cornford 1986; Scott et al. 2014). The emphasis here is on understanding the sediment and stone tool taphonomy in order to understand persistent rhythms of abandonment and reoccupation of this place.

\section{Home bases or persistent places?}

Persistent places are, historically speaking, some of the more important sites in the Palaeolithic canon. Long sequences with rich, well-stratified artefact collections have been used to chart culture histories of traditions, industries and technocomplexes. Sequences from sites as different in time, space and species as Klasies River Mouth (Singer \& Wymer 1982), the Mount Carmel complex (Garrod \& Bate 1937) and Combe Grenal (Bordes

(C) Antiquity Publications Ltd, 2016 
1972) have framed important debates about technological variability and its meaning, and about environmental impact on hominin behaviour. Previously, these sequences have been discussed in behavioural terms as home bases. This model began with site catchment analysis applied to Near Eastern and European Palaeolithic sites (Vita-Finzi \& Higgs 1970; Higgs 1975). Isaac (1978) further refined the concept, discussing central place foraging and the evolution of cultural behaviour. More recently, Rolland has defined a home base as:

A fixed location combining night sleep and protection of juvenile and defenceless individuals against natural elements and predation. It is the place where animal and vegetal foods are introduced, shared, and consumed, and a setting favouring the transmission of knowledge and behaviors through prolonged learning by the young of shared and transmitted technical, socio-economic, and cognitive repertoires necessary for ensuring group survival (Rolland 2004: 263).

He stresses the importance of fire in reorganising the day and night, allowing home bases to replace the older pattern of 'core areas'. Furthermore, he draws attention to the appearance of a home base settlement pattern during the later Middle Pleistocene (Rolland 2004: 25758). We differ from Rolland in that we see a wider role for hominin niche construction. Although we cannot know what occurred at these home bases, Rolland provides a plausible list. More to the point is evidence for repeated accumulation of materials, lithic artefacts and food residues at chosen localities. This niche construction (Odling-Smee 1993) aided hominins in their physical survival and shaped their cultural development. These places were more than refuges or learning environments. They were integral to becoming hominin in a cultural, behavioural and physical sense. Most importantly, such niche construction became an arena for the co-evolution of environment and hominin. Humans modified the natural affordances of place by using them-leaving material behind, rearranging the space, making fires - and, by using such places, subsequently became reliant upon the qualities of these 'artificially enhanced' natural places. Consequently, hominin and environment can no longer be separated as analytical concepts.

Schlanger (1992: 91) first used the term 'persistent place' when studying Anasazi settlement systems in Colorado, as a mechanism to link find-spots to concentrations of material, or 'sites' (see also Barton et al. 1995), and understanding patterns of occupation. Schlanger identified persistent places as localities with evidence for repeated use during long-term regional occupations, and specifically associated them with three key features:

1) unique qualities particularly suited to certain activities/behaviours;

2) natural features that focus reoccupations;

3) accumulations on landscapes resulting from extended occupation/revisitation independent of cultural features, but dependent on the presence of cultural material.

Significantly, Schlanger identifies landscape itself as persistent, and argues that cultural features within landscapes structure how they are used and reused. While we agree that landscape features may be persistent, adopting the co-evolutionary approach necessary for longer, Middle Pleistocene timescales requires that we acknowledge how landscapes themselves change in response to geological, ecological and cultural factors. Furthermore, it is the relationship between fixed places and shifting environments that makes 'persistence' 
a useful quality for investigating changing human landscapes, particularly during the deep time of the Pleistocene record.

\section{Persistence and the Palaeolithic}

In later periods, persistence is easy to identify; sites are defined by walls, ditches and settlement aggradations. This persistence, marked by accumulated materials, must, however, have a longer ancestry. We define Palaeolithic persistent places as those showing evidence for repeated and frequent use over long periods of time-both open and sheltered sites (e.g. caves and abris) over at least one interglacial phase. We view the emergence of persistent places as an intensification of deep-rooted hominin practices: the repeated use and discard of artefacts around waterholes in Africa (cf. Potts 1984) and Boxgrove (e.g. Pope \& Roberts 2005) representing the antecedents of our 'persistent places'.

Behaviours defining Palaeolithic persistent places are particularly evident in dense quantities of anthropogenic material within caves. This is due to accumulation and preservation patterns, as well as research focus. Of particular interest, however, is the revisiting of specific locations beyond inter-generational timescales. Persistence reflects humans having become increasingly habituated within landscape: particular paths and places being used more frequently, and the deposition of more material at them. Persistent places, therefore, are those at which humans leave material over geologically perceptible timeframes, irrespective of climate-driven change in local ecology and topography. Longterm persistence enables the changing use of fixed places with fixed affordances to be linked with changing landscapes and changing affordances in a given region. Thus it enables the identification and reconstruction of changes in how early humans structured their use of place and landscape. To illustrate this, we present new work conducted at La Cotte de St Brelade.

\section{La Cotte de St Brelade: an early Middle Pleistocene persistent place}

Predominantly an igneous island (Figure 2), Jersey drops from steep cliffs along the northern coast to low-lying southern bays. Pleistocene fluctuations in climate and sea level have profoundly affected the region; during cool-cold low-sea-level events, Jersey was a highelevation, terrestrial plateau connected to the continent, with large areas of intersected terrestrial landscape exposed to the south-west and the north. During warmer intervals, marine transgressions progressively isolated the island between two now submerged rivers to the north-west and the south (Figure 2b).

La Cotte itself is a T-shaped ravine system on the south-western corner of Jersey (Figure 3), formed through widening joints in the granite sea cliffs through marine erosion. These ravines captured sediments from at least 240000 years ago-aeolian and slope deposits rich in anthropogenic material, reflecting continuous occupation from MIS 7 to MIS 3, punctuated by abandonment during the coldest phases (Huxtable 1986; Bates et al. 2013). The La Cotte sediments were repeatedly truncated by rising sea level, with deposits in the North Ravine cut by the Eemian (MIS 5e) transgression.

(C) Antiquity Publications Ltd, 2016 


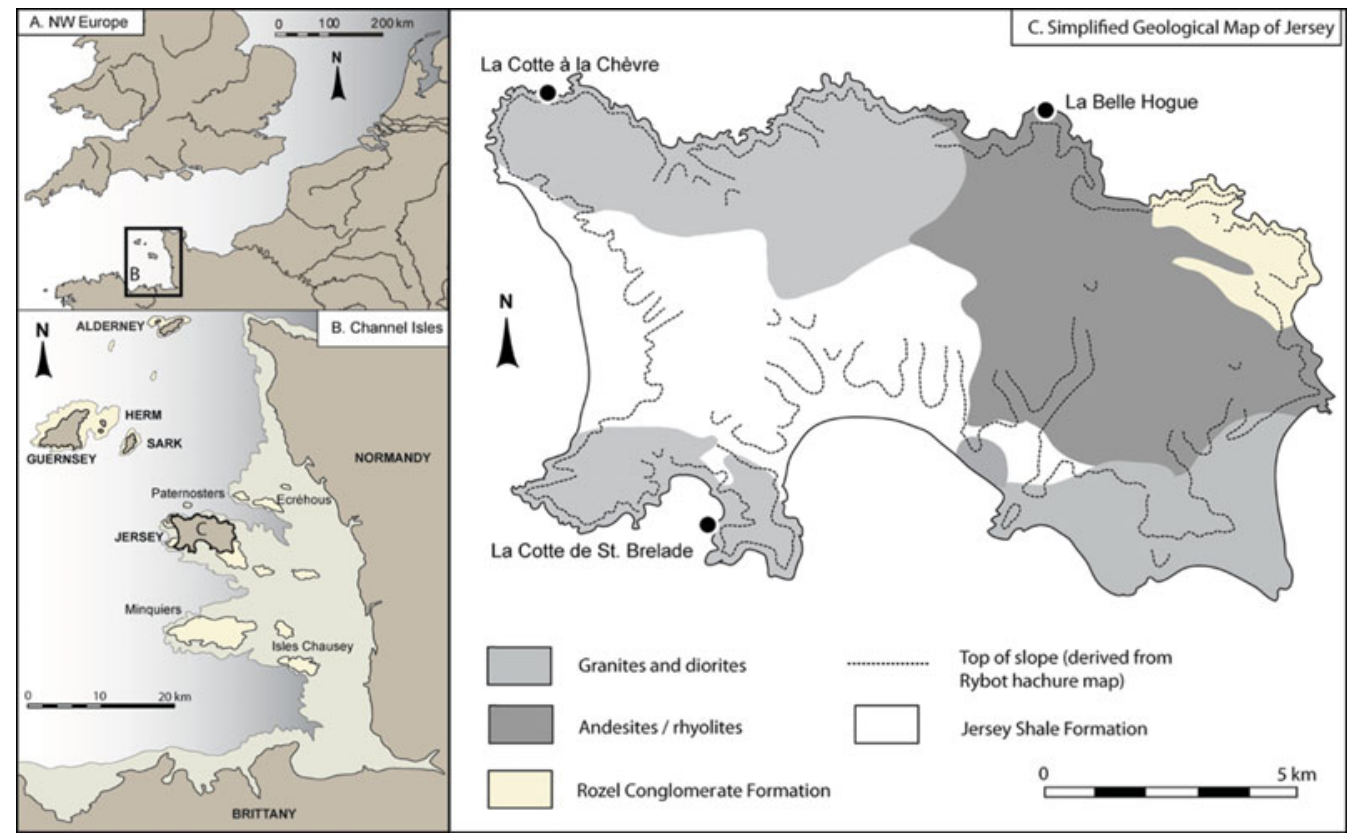

Figure 2. A) Channel Islands within north-western Europe; B) Jersey in relation to other Channel Islands and the French coast, showing the $-7 m$ drop in sea level necessary to reconnect to the continent; C) simplified geological map of Jersey, showing main sites. Based upon an image supplied by John Renouf, with permission.

The Middle Pleistocene sequence is over $5 \mathrm{~m}$ thick (Figure 4) and was excavated by Charles McBurney between 1961 and 1978, yielding $>100000$ lithic artefacts and $>10000$ faunal remains from 10 archaeological units (McBurney \& Callow 1971; Callow \& Cornford 1986), reflecting occupation during MIS 7/6.

The lowermost deposits form six units, predominantly temperate slope deposits containing thermophilous pollen (Layers H-C: Callow 1986a; Jones 1986). These layers are rich in Neanderthal lithic artefacts, partly reworked through ongoing slope processes. Layer E, however, represents a stable surface (soil developing on granitic sand), truncated and surmounted by deposits (Layers D-C) reflecting climatic deterioration (pollen and bone gelifraction). Temperate units $\mathrm{H}-\mathrm{C}$ are surmounted by slope and aeolian sediments assigned to six units (Layers B-6.1), reflecting cooling, culminating in two episodes of cold-climate loess deposition (Layers 3 and 6.1). The loessic levels reflect cold, steppe-tundra landscapes (Layers 3 and 6.1 both contain lemming) and are largely devoid of artefacts, but overlie units containing occupation debris. This includes two 'bone heaps' (top of Layer A/Layer 3 and Layer 5/base of 6.1), comprising cold, steppic fauna (Scott 1980, 1986).

The La Cotte sequence reflects a semi-continuous Neanderthal presence, punctuated by episodes when their behaviour was brought into sharper focus through sedimentary lacunae (e.g. soil formation) or increased sedimentation (loess deposition). Within the ravine, erosion and redeposition operates as a stochastic, climate-driven system. Erosion includes chemical and thermal weathering of the granite, resulting in rock fracture and deposition of head 


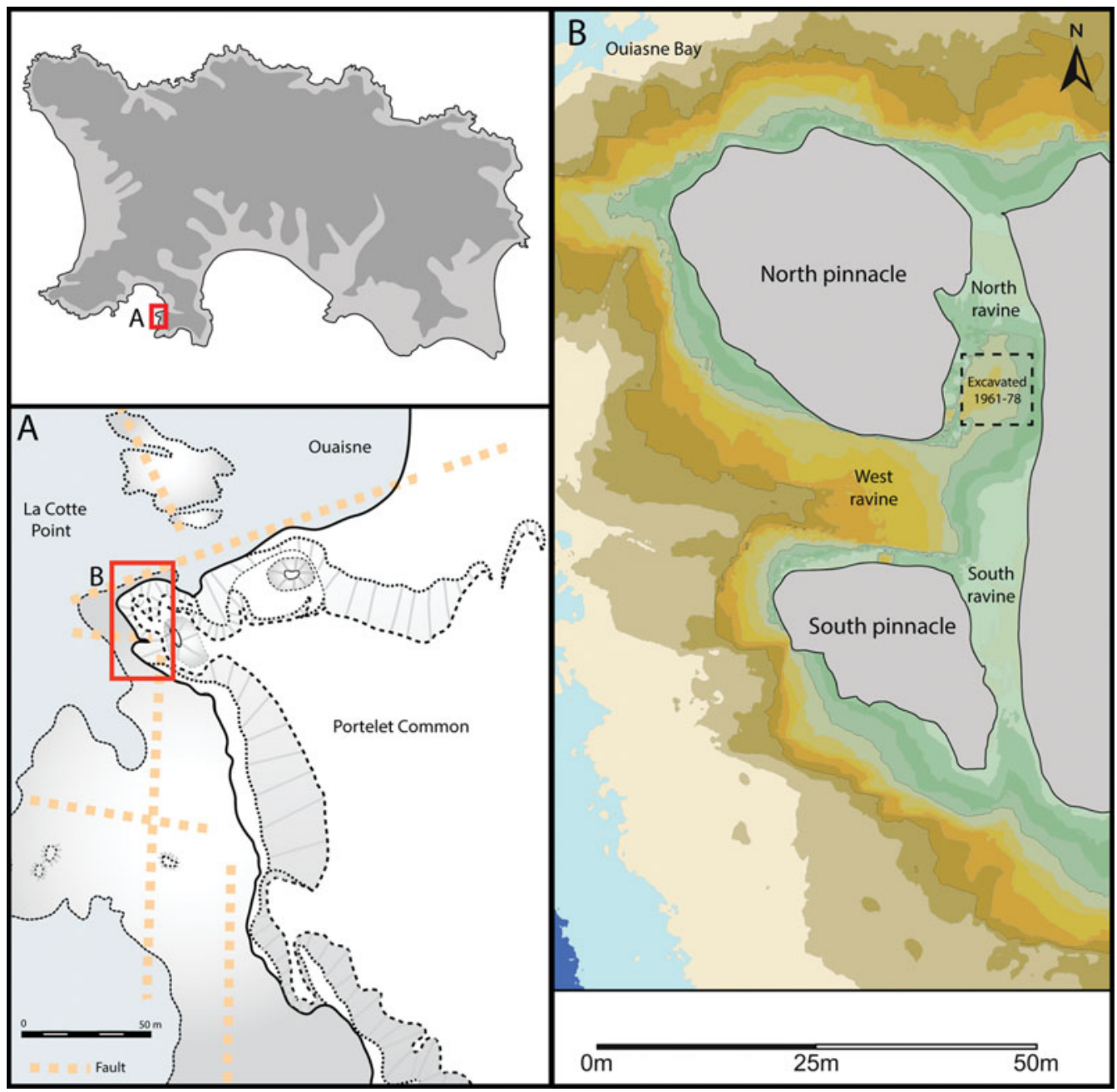

Figure 3. Location (A) and plan (B) of La Cotte ravine system. Grey areas represent hard granite walls of the ravine at $25 m$ asl, $2 m$ increments shown below.

deposits/granitic sands. Deposition of these products of erosion is augmented by the periodic input of loess during the coldest periods. These thick deposits protected existing sediments, forming the parent material that was subsequently further reworked as slope deposits. The shifting balance between these different processes allows repeated phases of human activity to be investigated at appropriate scales.

Neanderthals were present throughout temperate, cooling and cool conditions, returning while local environment, offshore topography and regional geography underwent dramatic shifts. Despite these profound changes in regional setting and local affordances, people continued to visit La Cotte, bringing tools with them. The cooler occupations of Layer A and Layer 5 occupations precede full steppe-tundra conditions, when humans were absent. Correlating occupation with the exact nature of these changes is complicated, but extreme (C) Antiquity Publications Ltd, 2016 


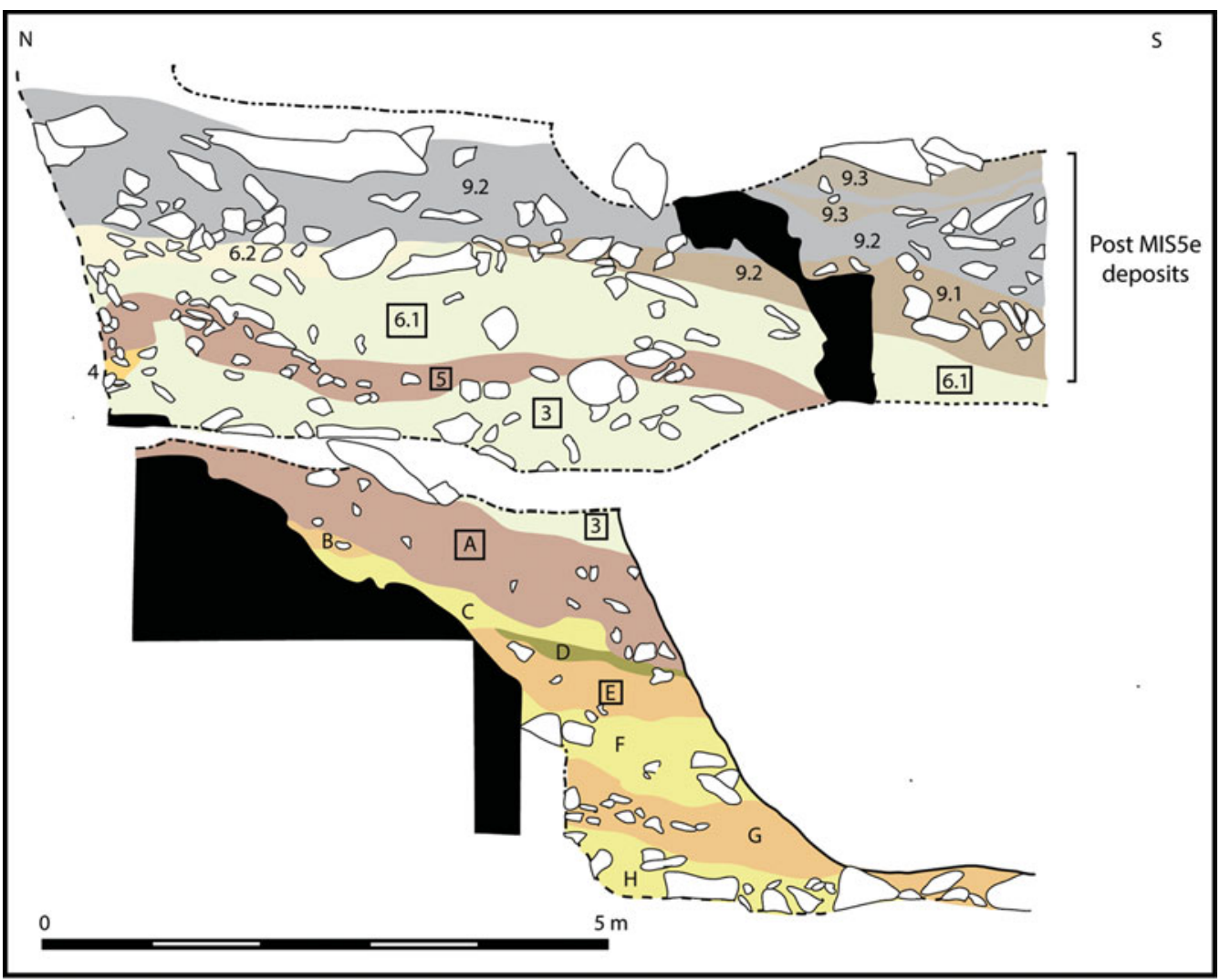

Figure 4. Composite section (west-facing) through the 'Saalian' (MIS 7/6) deposits infilling the North Ravine (modified from Callow 1986b: 61, fig. 6.6). Levels in boxes represent those discussed in the text. The section breaks vertically because it is a composite, stepped section through $E-W$ sloping deposits.

low sea level can be inferred for layers that reflect the coldest periods (Layers 3 and 6.1), with sea levels being low throughout the preceding period of cooling. Modelling precisely how marine regression affected the surrounding landscape is difficult, but a profoundly different regional geography prevailed during temperate conditions (Layer E) versus the cool-cold environments of Layers A and 5. Throughout the aggradation of these deposits, Jersey does not appear to have been an island as it is today; even during the warmest conditions of MIS 7, sea level remained at least 5-10m below modern levels (using the sea level curve of Waelbroeck et al.2002). A drop of $7 \mathrm{~m}$ would reconnect Jersey to the continent today. Climatic deterioration and falling sea level would have exposed a larger coastal plain extending towards the Channel River, with a drop in excess of $-30 \mathrm{~m}$ exposing the nearest bedrock flint source ( $20 \mathrm{~km}$ to the north).

To understand behaviour at La Cotte and in the wider region, we focus on lithic assemblages from three clearly defined units: Layer E, the top of Layer A, and Layer 5. These units represent subdivisions of a continually accumulating system, within which the input and modification of stone tools and faunal remains allows the relationship between site

(C) Antiquity Publications Ltd, 2016 


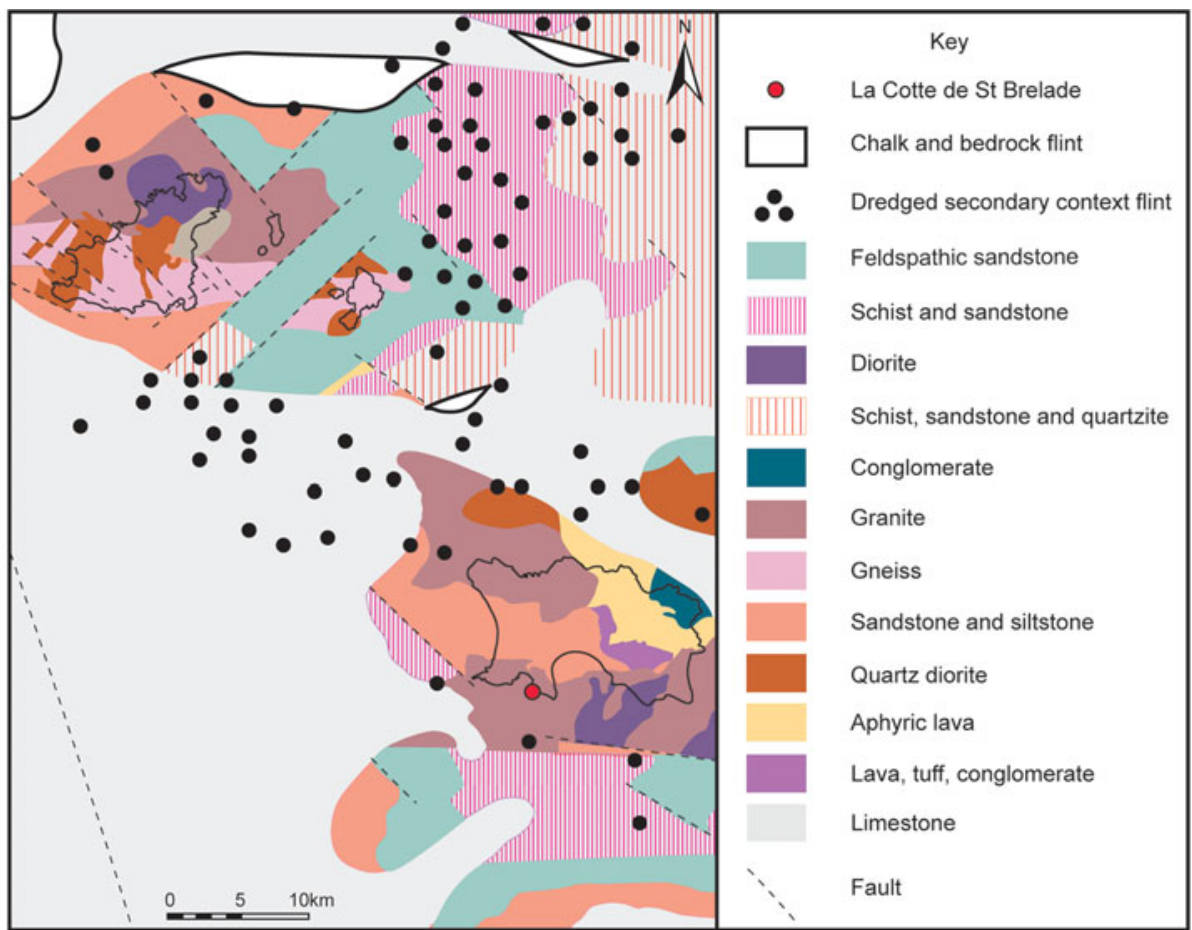

Figure 5. Bedrock geology of Jersey and the surrounding region today (data derived from Hommeril 1967; British Geological Survey 2000).

and landscape to be examined. A broad impression of occupation intensity can be inferred by contrasting artefact density with sedimentary regime (see Table 1): highly anthropogenic, temperate Layer $\mathrm{E}$ is much denser than the overlying layers associated with cooler climate occupation and loess deposition.

\section{Layer $E$}

Layer E reflects a broadly temperate interval, evidenced by clay illuviation (forest soil formation) (van Vliet-Lanoë 1986). At this point, Jersey was not an island, and La Cotte overlooked a substantial coastal landscape (now submerged). The deposits were rich in fragmented bone (461 NSP (Number of Specimens Primary)), around a third of which $(29.7 \%)$ was burnt. Burnt artefacts are also present (2.6\% of assemblage), reflecting fire setting during this occupation. Some 6339 lithic artefacts were recorded from around $3 \mathrm{~m}^{3}$ $\left(2113 \mathrm{artefacts} / \mathrm{m}^{3}\right)$ of excavated material, suggesting intense or repeated occupation. These artefacts are fresh (refitting material is present) with limited edge damage. Beach flint dominates ( $81.5 \%$ of sourceable flint); other raw materials are relatively rare (only $15.3 \%$ of the total assemblage). Some flint artefacts retain thicker, chalky (although chatter-marked) cortex, suggesting that some beaches may have been near bedrock, the closest of which is $20 \mathrm{~km}$ north of the site (see Figure 5). The presence of a few flint flakes $(2.8 \%)$ with unrolled fresh, chalky cortex might suggest that outcrops were also directly exploited. This (C) Antiquity Publications Ltd, 2016 
Table 1. La Cotte de St Brelade lithic artefact samples selected for analysis.

\begin{tabular}{|c|c|c|c|c|c|c|c|}
\hline Layer & $\begin{array}{c}\text { Lithic } \\
\text { artefacts } \\
>20 \mathrm{~mm}\end{array}$ & $\begin{array}{c}\text { Area } \\
\text { excavated } \\
\left(\mathbf{m}^{3}\right)\end{array}$ & $\begin{array}{c}\text { Lithic artefact } \\
\text { density } \\
\left(\text { per } \mathbf{m}^{3}\right)\end{array}$ & Description & Environment & Date & Affected by? \\
\hline Layer 5 & 3315 & 18.6 & 178.2 & bleached loessic loam & cool & MIS 6 & freeze-thaw, soil creep \\
\hline Layer A/3 & 628 & & & $\begin{array}{l}\text { intersection between base of Layer } 3 \\
\text { loess and underlying deposits of } \\
\text { Layer A }\end{array}$ & $\mathrm{cool} / \mathrm{cold}$ & MIS 7/6 & \\
\hline Top of Layer A & 4616 & 5.8 & 795.9 & rich occupation in loessic matrix & cool & MIS 7/6 & $\begin{array}{l}\text { ranker formation, } \\
\text { channelling of surface } \\
\text { (run-off): freeze-thaw }\end{array}$ \\
\hline Layer E & 6339 & 3.0 & 2113.0 & $\begin{array}{l}\text { occupation: burnt bone in granitic } \\
\text { sand matrix }\end{array}$ & temperate & MIS 7 & $\begin{array}{l}\text { soil formation: upper part } \\
\text { of soil eroded }\end{array}$ \\
\hline
\end{tabular}


combination of beach flint from a nearby source of bedrock during a period of temperate climate is intriguing, possibly suggesting a regional lag, or decoupling, of climate change and sea level.

The assemblage reflects a partial chaine opératoire; there is little cortical material and only a few cores considering the number of flakes present (with a core to flake ratio of 1:31). Notably, $40 \%$ of the cores are, themselves, on flakes. The predominant technological strategy is discoidal flaking; Levallois flaking is barely present. Bifaces are rare, although handaxe thinning flakes are present-many are retouched. The largest flakes were frequently used as flake tools and cores. As they were struck from beach cobbles, they may represent a deliberate provisioning strategy. Producing a series of flakes allows raw material to be assessed where it was acquired; only the least-flawed blanks were transported away for use elsewhere. Interestingly, there was little attempt to replace this flint with locally available non-flint material. This suggests that Layer $\mathrm{E}$ reflects repeated, short-term use of the site, rather than intense use of the local landscape, which would require provisioning of place using local raw materials.

\section{Layer $A$}

Layer $A$ is thick (around $1 \mathrm{~m}$ ) and comprises bone fragments in a loessic matrix, surmounted by loess (Layer 3). As climate deteriorated, the sea retreated to the north and west. Loess deposition may have also masked some relict sources of beach flint. Artefacts were analysed from the upper $50 \mathrm{~mm}$ (4616; the unit produced 40906 ), reflecting final occupation preceding deposition of the Layer 3 loess, together with 628 artefacts from the Layer A/Layer 3 boundary. The assemblage is unabraded, although some pieces exhibit light edge damage. The final stages of reduction dominate; an elegant method of rejuvenating the edges of small-medium flakes is noteable (Figure 6) —elongated flakes were removed at an oblique angle down one margin, usually from the distal end. Both retouched $51.3 \%$ of spalls) and unretouched flakes were re-sharpened in this way, but were rarely subsequently retouched, indicating that plain, sharp edges were perhaps required (cf. Cornford 1986). These (re)sharpened flakes, and the spalls themselves, are common (11.1\% of flint debitage); Neanderthals extended the life of their tools, before switching to lower-quality local raw materials. This technique allows flakes to be used again without becoming excessively small.

Cores were also reworked: most are discoidal, although some were originally Levallois cores. There are some bifacial tools (13), and thinning flakes are present (35). A few artefacts retain thick, chalky cortex ( $1.2 \%$ cortical debitage) indicative of bedrock sources, but such outcrops were not extensively exploited, with beach pebbles being more common. Other lithologies (from within $5 \mathrm{~km}$ ) were also used ( $21.0 \%$ of artefacts), suggesting that hominins were more locally active than during the Layer E occupation. Layer A has produced faunal remains exhibiting direct evidence for human interaction with medium- to mega-herbivores: green bone breakage, including conchoidal scars and flakes, as well as large notches with medullar flaking, i.e. parallel cone fractures. Cut marks have also been observed, and their location and orientations largely suggest defleshing.

This occupation reflects ongoing use of La Cotte as the climate cooled, with apparent abandonment during periods of extreme cold, as shown by the loess in Layer 3. Flakes and

(C) Antiquity Publications Ltd, 2016 


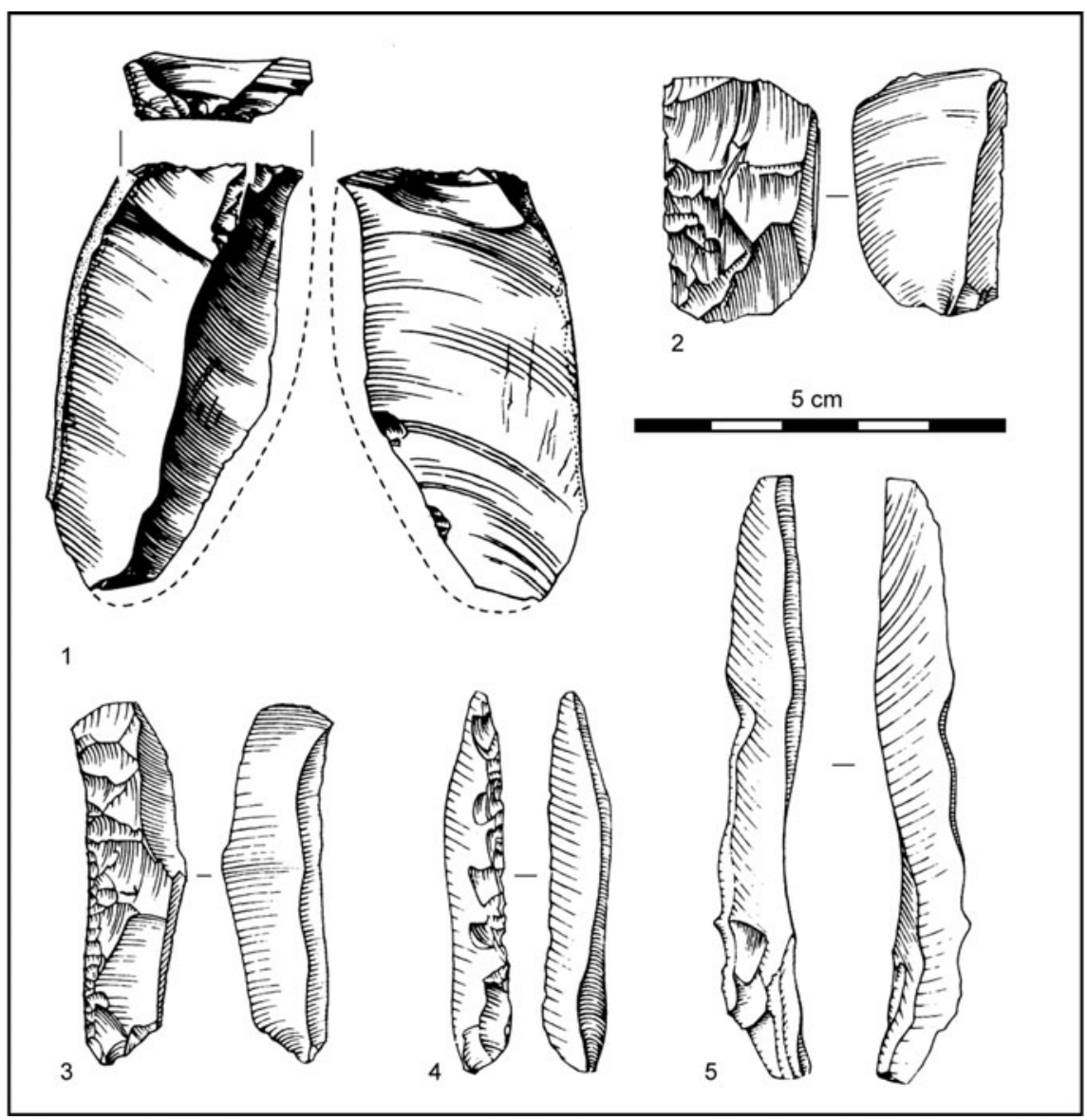

Figure 6. Artefacts with resharpening removals $\left(\begin{array}{l}1 \\ \&\end{array}\right)$ and resharpening spalls (3-5) from La Cotte, Layer A.

tools were resharpened to conserve the edges of a transported toolkit, potentially for butchery. Visits may have been brief because the flint-dominated toolkit was transported, reworked and conserved during occupation, and local lithologies were not extensively exploited. This unit reflects mobile groups exploiting cool, open environments within which La Cotte remained a focal point, although local setting and affordances had changed.

\section{Layer 5}

Layer 5 is a comparatively lower-density unit $\left(178.2\right.$ artefacts $\left./ \mathrm{m}^{3}\right)$ bracketed between loess Layers 3 and 6.1. It is a loessic colluvial loam containing bone and granite fragments rearranged by freezing (van Vliet-Lanoë 1986: 94). Sea level retreated further during these cold conditions, exposing landscapes towards the Channel River and revealing Cretaceous flint sources. The upper bone heap is embedded within Layer 5 (Callow 1986a: 81), although bones forming this pile are also attributed to the base of loessic Layer 6.1 above. 
Stratigraphically, therefore, the bone heap is within Layer 5, and the Layer 6.1 loess simply surmounts it.

Minimal post-depositional modification is apparent: the lithic assemblage is predominantly unabraded, with only light edge damage. Mammoth dominates the fauna, comprising $40 \%$ of the assemblage NSP with an MNI of 11 (Scott 1986). The excavators describe these bones as stacked against the western ravine wall, surmounted by two rhinoceros skulls (Scott 1986: 159). Neanderthal interaction with the fauna is evidenced by cut marks $(\mathrm{MNE}=5)$ and green bone breakages (conchoidal scars: $\mathrm{MNE}=23)$. Young and prime-age adults dominate, indicating human predation (Scott 1986), and little carnivore activity was identified $(\mathrm{MNE}=3)$, suggesting a primary anthropogenic input.

Layer 5 is dominated by non-flint material (61.9\%), including feldspathic sandstone and schist from local outcrops $5-10 \mathrm{~km}$ to the south-east (see Figure 5). Other material has come from farther afield, and many flint artefacts (37\% of cortical debitage) come from the bedrock outcrops to the north. This suggests both a low sea level $(>-25 \mathrm{~m})$ to expose such sources, and that before coming to La Cotte, people were active over a considerable area.

The assemblage does not reflect initial core working; cortical material is rare. Large flakes (often Levallois and mostly flint) were carried to the site. Cores (generally on beach cobbles) would have always been too small to produce such flakes. These were frequently retouchedoften heavily, and involving multiple phases, so that edges are steep relative to blank thickness. Many are broken and can be refitted. Local lithologies were treated differently: refitting sequences involving 12-20 pieces are present, reflecting on-site reduction of cores roughed-out elsewhere. Flint cores, however, are always reduced down when discarded.

This layer represents a restricted occupation associated with the upper bone heap. Humans were the main agents of bone accumulation, as suggested by cut marks, green bone breakage, a lack of carnivore activity, mammoth age structure and the spatial arrangement of the bones. Stone tool distribution clearly relates to the distribution of the bones (see Figure 7), suggesting that they were present, and that stone-working was undertaken around them.

Neanderthals carried in flint from a wide area north of the site, reflecting the low sea level (early glacial?) landscape within which they were active. These toolkits were extensively modified in transit, and local materials were used in a more expedient fashion. This dominance of local, although not immediately available, raw material, suggests an emphasis on provisioning the site in a way that is not apparent in the other units studied, reflecting more intense use of the local landscape; this material was brought, already prepared, into the site from a $5-10 \mathrm{~km}$ radius. This implies a markedly different use of the same place; rather than repeated use of the site as part of a pattern of short-term, long-distance movements. Rather, they were occupying the local landscape, although assemblage size and density $\left(178.5 / \mathrm{m}^{3}\right)$ suggest that this phase of site use may have been short.

\section{Conclusion}

The presence of artefacts and bones bearing traces of processing throughout the sediments that infilled La Cotte from at least 240000 years ago until after 40000 years ago (Bates et al. 2013) demonstrates that this place had 'persistence' within the Neanderthal landscapes of the region. The granite headland itself, and the ravine system cut into it, is an erosion-resistant (C) Antiquity Publications Ltd, 2016 


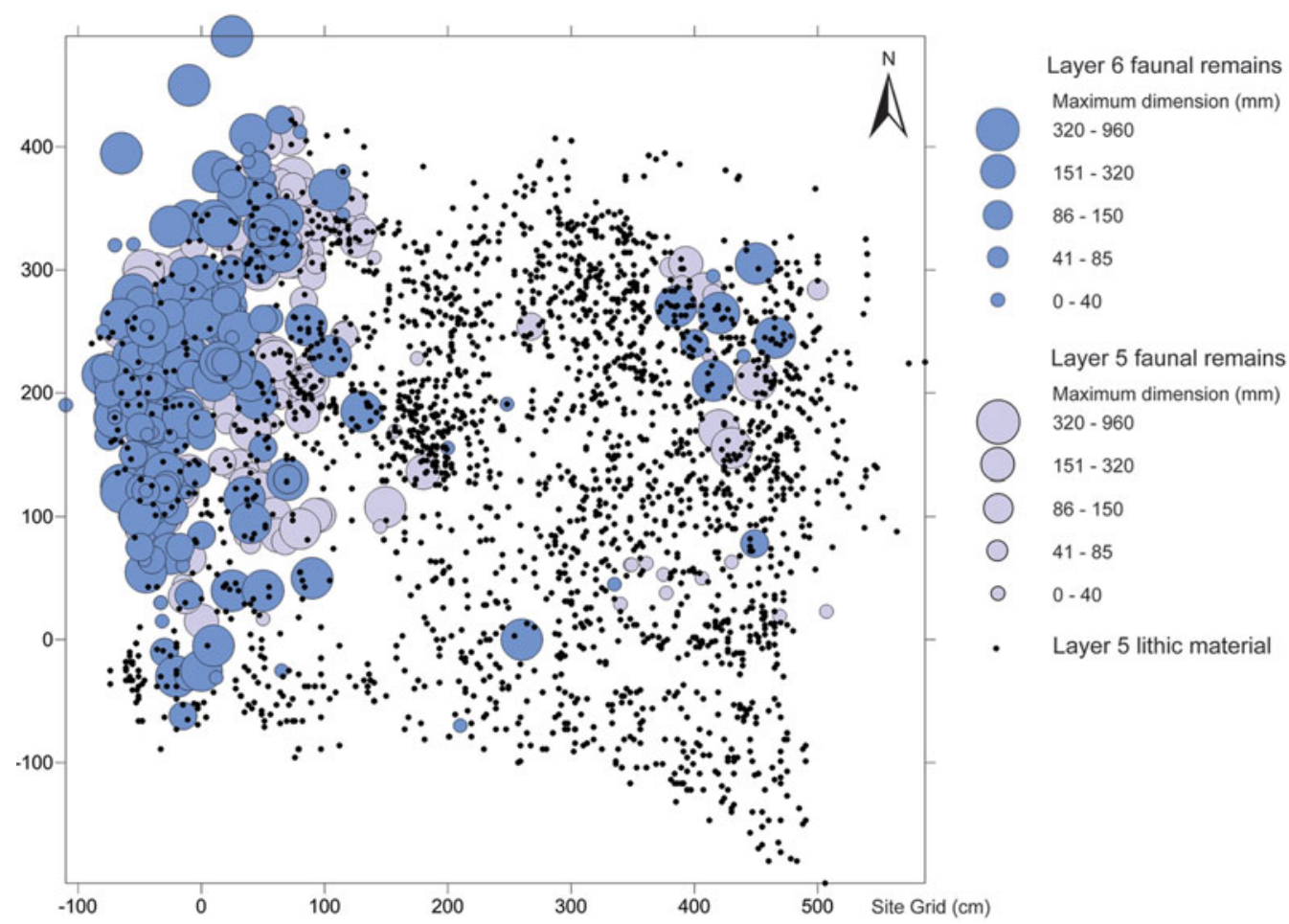

Figure 7. Distribution plan offaunal material from Layers 5 and 6.1, and lithic artefacts from Layer 5 showing distribution of lithics around the main bone concentration.

landform that retains sediment today. During times of lowered sea level, the ravines offered a degree of shelter, together with views over the now submerged landscapes to the south (Scott et al. 2014). The headland was widely visible, just as the Channel Islands, France and semi-submerged rock formations are today. It may therefore have acted as a navigation point for people moving through the now submerged offshore zone. La Cotte was constantly visited, despite shifts in climate and concomitant changes in regional landscape and environment. Moreover, the nature of occupation varied at different times. The temperate climate occupation recorded in Layer E reflects repeated short-term occupations by people carrying a transported, expedient toolkit. In contrast, the people who discarded the material present in Layer 5 stayed for longer within this area, using La Cotte as a temporary base-as marked by the transition to local lithologies.

What is critical, however, is the role that the place itself played in early Neanderthal movements around the landscape. The transported and resharpened toolkits of the final Layer A occupation and the curated flint tools from Layer 5, for instance, attest to extended journeys, some exceeding $20 \mathrm{~km}$. Although it is impossible to be sure how long such moves took (feasibly within a day), toolkit reworking might suggest that more time (perhaps several days) was spent travelling, alongside other activities. Social composition would have had an impact on travelling time, with young children carried, if not moving more slowly than 
adults. Regardless of actual time spent in transit, the journey itself could be viewed as a deliberate, strategic move to the site, suggesting that La Cotte played a structuring role in how humans thought of the landscapes through which they moved. It is noteable that although the headland, as a highpoint, would have had enhanced visibility, it is unlikely to have been visible over the distances people were travelling: today, Jersey drops below the horizon around $5 \mathrm{~km}$ offshore if one walks out south-east of the island on a spring tide. La Cotte therefore provides an insight into early Neanderthal 'landscapes of mind': places distant in time and space conceived of as a destination around which life was organised. Not only were these places physically persistent (in that they resist erosion in a changing landscape), but mentally persistent, attracting human attention—drawing people not only over the days necessary to journey there, but over the tens of thousands of years of climatic change that the sequence records.

La Cotte was a persistent place because of the features it possessed (prospect, shelter, way-marker), but also because of the importance that people invested in it by travelling there time and again. This interaction between people and place is a mutual, deep-rooted one: people active around the Q1B waterhole at Boxgrove, southern England, over 500000 years ago, for instance, would have recognised and related to the traces left by people who had passed that way before (Pope \& Roberts 2005), and similar parts of the Boxgrove palaeolandscape were used for similar purposes over time. This pattern intensifies, however, after 300000 years ago. In particular, the chaine opératoire became increasingly disaggregated in time and space with the adoption of Levallois flaking (White \& Pettitt 1995). Early Middle Palaeolithic sites in the Thames Valley reflect an increasingly logistical approach to how technology was organised in the landscape-from late MIS 8 onwards, particular places were used for particular purposes- 'gearing up' at dedicated extraction and provisioning sites with transportable equipment to meet needs elsewhere in the landscape (Scott 2011). These places share the quality of persistence with La Cotte, while lacking its deep sequence, and the ability to look beyond the site to movements through the landscape that varied raw materials (rather than just flint) allow.

Persistence, therefore, is a quality shared by a continuum of land-use practices-linking Oldowan artefact concentrations, on one hand, to the songlines of the Wardaman people (Norris \& Harney 2014), and medieval pilgrim shrines (Powell 2014) on the other. The organisation of human movement around particular persistent places reflects the same "release from proximity" (Gamble 1998: 443) that has been suggested to be necessary to deal with larger social groups, and arguably is attested by the technological changes apparent from around 300000 years ago (e.g. the widespread adoption of Levallois flaking; White $\&$ Pettitt 1995). Similarly, the apparent shift towards more efficient carnivory through selective hunting (Stiner et al. 2009) is an index for this cognitive capacity to plan and predict through mutual engagement between human and animal actors. We see persistent places as mutually constituted; the natural affordances of such places affect how people use them, while this use in turn enhances their importance in structuring social life. Places that groups return to repeatedly are invested with the qualities of the interactions that have taken place before-whether they are held in direct memory, or inferred from observable traces (old fireplaces, reused lithics, bone refuse). A persistent place possesses different qualities as a locale (Gamble 1998) to a transient camp because it is overlain with this enhanced patina

(C) Antiquity Publications Ltd, 2016 
of extended social life. Indeed, the process by which places become persistent is the same process by which landscapes become encultured and mapped.

\section{Acknowledgements}

This research has been funded by the AHRC as part of the Crossing the Threshold Project (AH/K00378X/1). Grateful thanks are extended to Jersey Heritage and the Société Jersiaise for their support, and in particular to Olga Finch, Neil Mahrer, Jon Carter, Ralph Nichols, John Renouf, John Clarke and Neil Molyneux, as well as to Peter Hoare and Anne-Lyse Ravon for work on the raw materials, and to Rob Hosfield and an anonymous reviewer for their comments. Beccy Scott would also like to acknowledge the support of the Calleva Trust (Pathways to Britain) project.

\section{References}

Aiello, L. \& R. Dunbar. 1993. Neocortex size, group size and the evolution of language. Current Anthropology 34: 184-93. http://dx.doi.org/10.1086/204160

Ashton, N., S.G. LeWIS \& C. STRINGER (ed.). 2011. The ancient human occupation of Britain (Developments in Quaternary Science 14). Amsterdam: Elsevier.

BARHAM, L.S. 2010. A technological fix for 'Dunbar's dilemma'?, in R. Dunbar, C. Gamble \& J.A.J. Gowlett (ed.) Social brain, distributed mind: 367-89. Oxford: Oxford University Press. http://dx.doi.org/10.5871/bacad/9780197264522. 003.0018

Barton, R.N.E., P.J. Berridge, M.J.C. Walker \& R.E. BEVINS. 1995. Persistent places in the Mesolithic landscape: an example from the Black Mountain Uplands of South Wales. Proceedings of the Prehistoric Society 61: 81-116. http://dx.doi.org/10.1017/S0079497X00003042

Bates, M., M.I. Pope, A. Shaw, B. ScotT \& J.-L. SCHWENNINGER. 2013. Late Neanderthal occupation in north-west Europe: rediscovery, investigation and dating of a last glacial sediment sequence at the site of La Cotte de Saint Brelade, Jersey. Journal of Quaternary Science 28: 647-52. http://dx.doi.org/10.1002/jqs.2669

Bordes, F. 1972. A tale of two caves. New York: Harper \& Row.

British Geological Survey. 2000. Guernsey sheet $49 \mathrm{~N}-$ $04 \mathrm{~W}$ solid geology. Keyworth: British Geological Survey.

ButZER, K.W. \& G.L. IsAaC (ed.). 1975. After the Australopithecines. The Hague: Mouton.

CALlow, P. 1986a. Interpreting the La Cotte sequence, in P. Callow \& J.M. Cornford (ed.) La Cotte de St. Brelade 1961-1978. Excavations by C.B.M. McBurney: 73-82. Norwich: Geo.

- 1986b. The stratigraphic sequence: description and problems, in P. Callow \& J.M. Cornford (ed.) $L a$ Cotte de St. Brelade 1961-1978. Excavations by C.B.M. McBurney: 55-71. Norwich: Geo.
Callow, P. \& J.M. Cornford (ed.). 1986. La Cotte de St. Brelade 1961-1978. Excavations by C.B.M. McBurney. Norwich: Geo.

CORNFORD, J.M. 1986. Specialised resharpening techniques and evidence of handedness, in P. Callow \& J.M. Cornford (ed.) La Cotte de St. Brelade 1961-1978. Excavations by C.B.M. McBurney: 337-52. Norwich: Geo.

DUNBAR, R.I.M. 1992. Neocortex size as a constraint on group size in primates. Journal of Human Evolution 20: 469-93. http://dx.doi.org/10.1016/0047-2484(92)90081-J

GAMBLE, C.S. 1998. Palaeolithic society and the release from proximity: a network approach to intimate relations. World Archaeology 29: 426-49. http: //dx.doi.org/10.1080/00438243.1998.9980389

- 2013. Settling the Earth: the archaeology of deep human history. Cambridge: Cambridge University Press.

Gamble, C.S., J.A.J. Gowlett \& R. Dunbar. 2014. Thinking big: the archaeology of the social brain. London: Thames \& Hudson.

Garrod, D.A.E. \& D.M.A. Bate. 1937. The Stone Age of Mount Carmel. Oxford: Clarendon.

Green, R.E., J. Krause, A.W. Briggs, T. Maricic, U. Stenzel, M. Kircher, N. Patterson, H. Li, W. Zhai, M. H.-Y. Fritz, N.F. HANSEN, E.Y. Durand, A.-S. Malaspinas, J.D. Jensen, T. Marques-Bonet, C. Alkan, K. PrÜfer, M. Meyer, H.A. Burbano, J.M. Good, R. Schultz, A. Aximu-Petri, A. Butthof, B. HÖBER, B. HöFFNER, M. SIEgEMUND, A. Weihmann, C. Nusbaum, E.S. Lander, C. Russ, N. Novod, J. AfFourtit, M. EgHOLM, C. Verna, P. Rudan, D. Brajkovic, Ž. Kucan, I. GuŠIC, V.B. DORONICHEV, L.V. Golovanova, C. Lalueza-FoX, M. DE la Rasilla, J. Fortea, A. Rosas, R.W. SCHMitZ, P.L.F. JOHNSON, E.E. Eichler, D. Falush, E. Birney, J.C. Mullikin, M. Slatkin, R. Nielsen, J. Kelso, M. Lachmann, D. ReICH \& S. PäÄBO. 2010. A draft sequence of the Neandertal genome. Science 328: 710-22.

http://dx.doi.org/10.1126/science.1188021

(C) Antiquity Publications Ltd, 2016 
Higgs, E.S. (ed.). 1975. Palaeoeconomy. Cambridge: Cambridge University Press.

Hommeril, P. 1967. Étude de géologie marine concernant le littoral Bas-Normand et la zone pré-littorale de l'Archipel Anglo-Normand. Unpublished PhD dissertation, University of Caen.

Huxtable, J. 1986. The thermoluminesence dates, in P. Callow \& J.M. Cornford (ed.) La Cotte de St. Brelade 1961-1978. Excavations by C.B.M. McBurney: 145-49. Norwich: Geo.

ISAAC, G. 1978. The food sharing behaviour of proto-human hominids. Scientific American 238: 90-108. http:

//dx.doi.org/10.1038/scientificamerican0478-90

JONES, R.L. 1986. The flora and vegetation of La Cotte de St. Brelade and its environs, in P. Callow \& J.M. Cornford (ed.) La Cotte de St. Brelade 1961-1978. Excavations by C.B.M. McBurney: 99-106. Norwich: Geo.

KLEIN, R.G. 2008. Out of Africa and the evolution of human behaviour. Evolutionary Anthropology 17: 267-81. http://dx.doi.org/10.1002/evan.20181

MCBrearty, S. \& A.S. BroOKS. 2000. The revolution that wasn't: a new interpretation of the origin of modern humans. Journal of Human Evolution 39: 453-563.

http://dx.doi.org/10.1006/jhev.2000.0435

McBurney, C.B.M. \& P. Callow. 1971. The Cambridge excavations at La Cotte de St Brelade, Jersey-a preliminary report. Proceedings of the Prehistoric Society 37: 167-207. http://dx.doi.org/10.1017/S0079497X00012627

McNabB, J., F. BinYon \& L. HazelWOOD. 2004. The large cutting tools from the South African Acheulean and the question of social traditions. Current Anthropology 45: 653-77. http://dx.doi.org/10.1086/423973

Mellars, P.A. \& C. STRINGER (ed.). 1989. The human revolution: behavioural and biological perspectives on the origins of modern humans. Edinburgh: Edinburgh University Press.

Mellars, P., O. Bar-Yosef, C. Stringer \& K.V. BOYLE (ed.). 2007. Rethinking the human revolution. Cambridge: McDonald Institute for Archaeological Research.

NorRIS, R.P. \& B.Y. HARNEY. 2014. Songlines and navigation in Wardaman and other Aboriginal cultures. Journal of Astronomical History and Heritage 17: 141-48.

ODLING-SMEE, F.J. 1993. Niche construction, evolution and culture, in T. Ingold (ed.) Companion encyclopedia of anthropology: humanity, culture and social life: 162-96. London: Routledge.
Pope, M.I. \& M.B. Roberts. 2005 Observations on the relationship between Palaeolithic individuals and artefact scatters at the Middle Pleistocene site of Boxgrove, UK, in C.S. Gamble \& M. Porr (ed.) The hominid individual in context: archaeological investigations of Lower and Middle Palaeolithic, landscapes, locales and artefacts: 81-97. London: Routledge.

POTTS, R. 1984. Hominid hunters? Problems of identifying the earliest hunter/gatherers, in R. Foley (ed.) Hominid evolution: 129-66. New York: Academic.

Powell, H.C. 2014. Pilgrimage, performance and miracle cures in the twelfth-century Miracula of St Aebbe, in E. Gemi-Iordanou, S. Gordon, R. Matthew, E. McInnes \& R. Pettitt (ed.) Medicine, healing and performance: 71-85. Oxford: Oxbow.

RightmiRE, G.P. 2004. Brain size and encephalization in Early to Mid-Pleistocene Homo. American Journal of Physical Anthropology 124: 109-23. http://dx.doi.org/10.1002/ajpa.10346

Rolland, N. 2004. Was the emergence of home bases and domestic fire a punctuated event? A review of the Middle Pleistocene record in Eurasia. Asian Perspectives 43: 248-80. http://dx.doi.org/10.1353/asi.2004.0027

SCHLANGER, S.H. 1992. Recognizing persistent places in Anasazi settlement systems, in J. Rossignol \& L. Wandsnider (ed.) Space, time and archaeological landscapes: 91-112. New York: Springer.

ScOTT, B. 2011. Becoming Neanderthals: the Earlier British Middle Palaeolithic. Oxford: Oxbow.

Scott, B., M. Bates, R. Bates, C. Conneller, M. Pope, A. Shaw \& G. Smith. 2014. A new view from La Cotte de St Brelade, Jersey. Antiquity 88: 13-29. http://dx.doi.org/10.1017/S0003598X00050195

ScOTT, K. 1980. Two hunting episodes of Middle Palaeolithic age at La Cotte de Saint Brelade, Jersey. World Archaeology 12: 137-52. http: //dx.doi.org/10.1080/00438243.1980.9979788

- 1986. The bone assemblages from layers 3 and 6 , in P. Callow \& J.M. Cornford (ed.) La Cotte de St. Brelade 1961-1978. Excavations by C.B.M. McBurney: 159-85. Norwich: Geo.

SHEA, J.J. 2011. Homo sapiens is as Homo sapiens was: behavioural variability versus 'behavioural modernity' in Palaeolithic archaeology. Current Anthropology 52: 1-35. http://dx.doi.org/10.1086/658067

Singer, R. \& J. WyMER.1982. The Middle Stone Age at Klasies River Mouth in South Africa. Chicago (IL): University of Chicago Press. 
STINER, M.C. 2002. Carnivory, coevolution, and the geographic spread of the genus Homo. Journal of Archaeological Research 10: 1-64. http://dx.doi.org/10.1023/A:1014588307174

STINER, M.C., R. BARKAI \& A. GOPHER. 2009. Cooperative hunting and meat sharing 400-200 kya at Qesem Cave, Israel. Proceedings of the National Academy of Sciences of the USA 106: 13207-12.

http://dx.doi.org/10.1073/pnas.0900564106

VAN VLIET-LANOË. 1986. Micromorphology, in P. Callow \& J.M. Cornford (ed.) La Cotte de St. Brelade 1961-1978. Excavations by C.B.M. McBurney: 91-96. Norwich: Geo.
Vita-Finzi, C. \& E.S. Higgs. 1970. Prehistoric economy in the Mount Carmel area of Palestine, site catchment analysis. Proceedings of the Prehistoric Society 36: 1-37.

Waelbroeck, C., L. Labeyrie, E. Michel, J.C. Duplessy, J.F. MCMANus, K. LAMBECK, E. BALbon \& M. LabraCherie. 2002. Sea-level and deep water temperature changes derived from benthic foraminifera isotopic records. Quaternary Science Reviews 21: 295-305. http: //dx.doi.org/10.1016/S0277-3791(01)00101-9

White, M.J. \& N.M. Ashton. 2003. Lower Palaeolithic core technology and the origins of the Levallois method in north-western Europe. Current Anthropology 44: 598-609. http://dx.doi.org/10.1086/377653

White, M. \& P. PetTitT. 1995. Technology of Early Palaeolithic Western Europe: an heuristic framework. Lithics 16: 27-40.

Received: 23 August 2015; Accepted: 23 December 2015; Revised: 28 January 2016 